\title{
Asset Portfolios and Food Accessibility in Sekhukhune District, Limpopo Province, South Africa
}

\author{
Phokele Maponya ${ }^{1} \&$ Shadung Moja ${ }^{1}$ \\ ${ }^{1}$ Department of Environmental Science, University of South Africa, Florida Campus, Roodepoort, South Africa \\ Correspondence: Phokele Maponya, Department of Environmental Science, University of South Africa, Private \\ Bag X6 Florida 1710, South Africa. Tel: 27-114-712-285. E-mail: maponpi@unisa.ac.za
}

Received: June 30, 2012 Accepted: July 16, 2012 Online Published: October 12, 2012

doi:10.5539/jas.v4n11p144 URL: http://dx.doi.org/10.5539/jas.v4n11p144

\begin{abstract}
This study aims to analyse household food accessibility categories (food insecure, vulnerable, marginal and food secure) of rural households in Sekhukhune district of Limpopo province. Five wards were identified for the study in the Mamone village namely: Matsoke, Ga Manyaka, Manyelethi, Magolwaneng and Maroteng. These wards had approximately the same number of households. Ten households from each ward were randomly selected. Based on comprehensive food security and vulnerability analysis over 70 per cent of the sampled households were food insecure. Major asset portfolios determining food accessibility included gender, employment, education level, water source, finance, income source, monthly expenditure and type of dwelling. Policy measures directed towards the provision of household assets should be given adequate attention and priority by the Government.
\end{abstract}

Keywords: household food security, Sekhukhune district, household assets, Limpopo province, South Africa, policy

\section{Introduction}

Sekhukhune district which was declared as one of the districts that is food insecure, and one of the poorest in the country (Mbeki, 2005). It is in the same district where 33 per cent of the population still depends on natural water supply, unemployment is at 61.1 per cent and 7 per cent have no formal sanitation ( StatsSA, 2003). On a national scale only 19 per cent of the total South African population still depends on natural water supply, unemployment is at 25.2 per cent and 33 per cent lack basic sanitation services (StatsSA, 2006). According to StatsSA (2006) government support plays an important role in providing income for households, where old age and child support grants are being received by a third of households. Only 27 percent of households receive income from regular wage employment (StataSA, 2006). Female headed households constitute a significant number of the economically active population in Sekhukhune district as most of the males are migrant workers (StatsSA, 2006). It is further stated by Vogel and Smith (2002) that about 31 percent of households in Sekhukhune receive remitted income from migrant laboures. This is a serious concern because according to FAO (2006) female headed households usually are the most vulnerable and food insecure households.

The state of household income in South Africa is worsening daily. Fifty three percent (16.4\%) of South Africa's adult population is excluded from formal financial services (Financial scope, 2005). It must be noted that 99 percent of those without access to financial service are black, 49 percent of these people live in rural areas and 55 percent are women (Fin scope, 2005). It is very clear from the above statistics that rural household's ability to save and invest is minimal. This is a serious problem that rural households face because without access to financial service, they will experience a lack of production opportunities, employment scarcity and an inability to build asset base. This will affect rural household's income badly because sustainable livelihoods require creating of assets and enhancing savings, this in turn can pave way for households to participate in economic activities (Gass \& Heierli, 2000).

Such adverse circumstances increase households' chances of disability, illness, poor education, suffering, violence, abuse and unemployment, and eventually resulting in households' inability to produce enough food to feed their families. Thus, it is important to seek strategies to improve the food access in Sekhukhune. In order to address the food access in Sekhukhune it is important to compile an asset portfolio of a sample of the households. Asset portfolio will help in planning future food access strategies. 


\section{Materials and Methods}

Limpopo Province is South Africa's northernmost province, lying within the great curve of the Limpopo River (StatsSA, 2006). It is the gateway to the rest of Africa, with its shared borders making it favourably situated for economic cooperation with other parts of Southern Africa. The greater Sekhukhune District (see Figure 1) is one of five districts in Limpopo province. It is a cross-boundary district between the Limpopo and Mpumalanga Provinces. Mamone village which is characterised by red sands and rocky outcrops lies in the Sekhukhune district. Its inhabitants are the descendants of the Great Sekwati, and Mamone is often indicated, together with villages like Mohlaletsi and Madibong, as one of the places where the real Pedi customs are still followed.

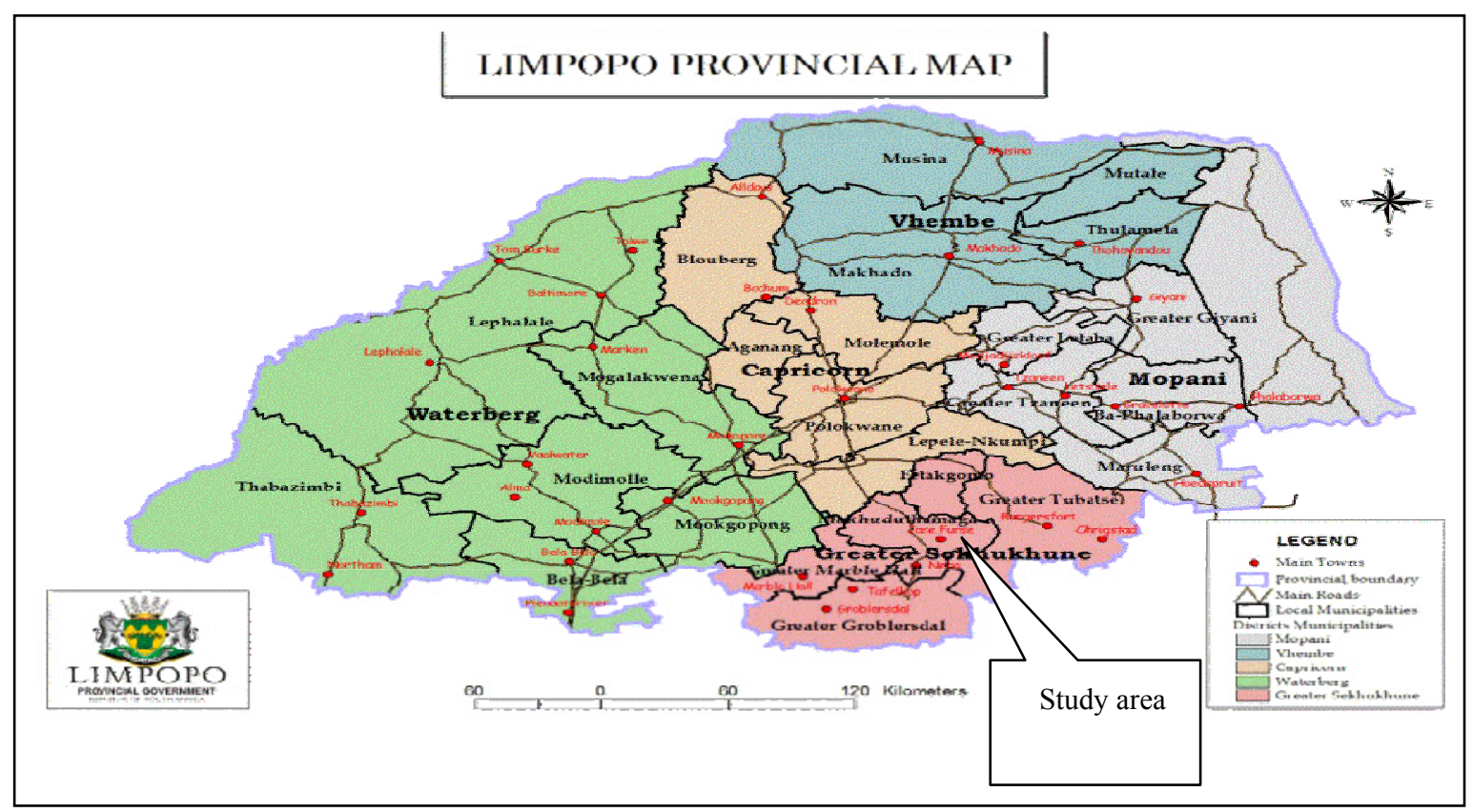

Figure 1. Geographic location of the Greater Sekhukhune district, Limpopo Province (StatsSA, 2006)

Vulnerability to food insecure undermines the ability of people to develop livelihood strategies, adaptive behaviours and coping strategies which help to ensure long-term food security. Figure 2 shows vulnerability map of South Africa showing vulnerability "hotspots". It should be noted that areas with more than 80 percent of households being in a state of poverty are likely to be food inaccessibility "hotspots" of South Africa. Limpopo province falls under 60-85 percent category. Two vulnerability groups can be identified namely; The first group-the economically marginalized-lack land, capital and tools, livestock, literacy and other formal skills. They make up the 'working poor' or the 'under-employed poor'. The second group-the socially marginalized-are vulnerable because of gender (women and girls); age (children and the elderly) or by illness or disability. This group is often also economically marginalized and form the core of the chronically poor. They usually have fewer coping options at their disposal.

This research used a quantitative design as questionnaires were used to generate data. During the first research visit after permission to conduct research in the village was granted by the chief, the questionnaires were explained to the local authorities. Two assistants were selected and trained in data collection. The importance of the study and data quality management was explained to them. The assistants also played a role in giving directions in the village since the village was fairly large and has unplanned geographical layout. The assistants relied on different landmarks to identify different wards. It was also important as part of ploughing back to the communities to empower local people with knowledge; here the assistants had an opportunity to learn more about data collection approaches.

The wards were selected using cluster random sampling. The community was divided into clusters along geographic boundaries. The data for the study was obtained from the randomly selected households. Sampling of households involved obtaining a sample frame of households from the chief. Households were then randomly selected. The study was conducted in one village, Mamone. This village was selected purposively because of poor 
socio-economic development. Five wards were identified namely Matsoke, Ga Manyaka, Manyelethi, Magolwaneng and Maroteng, which had approximately the same number of households. Ten households from each ward were randomly selected to form a total of 50 households for the study.

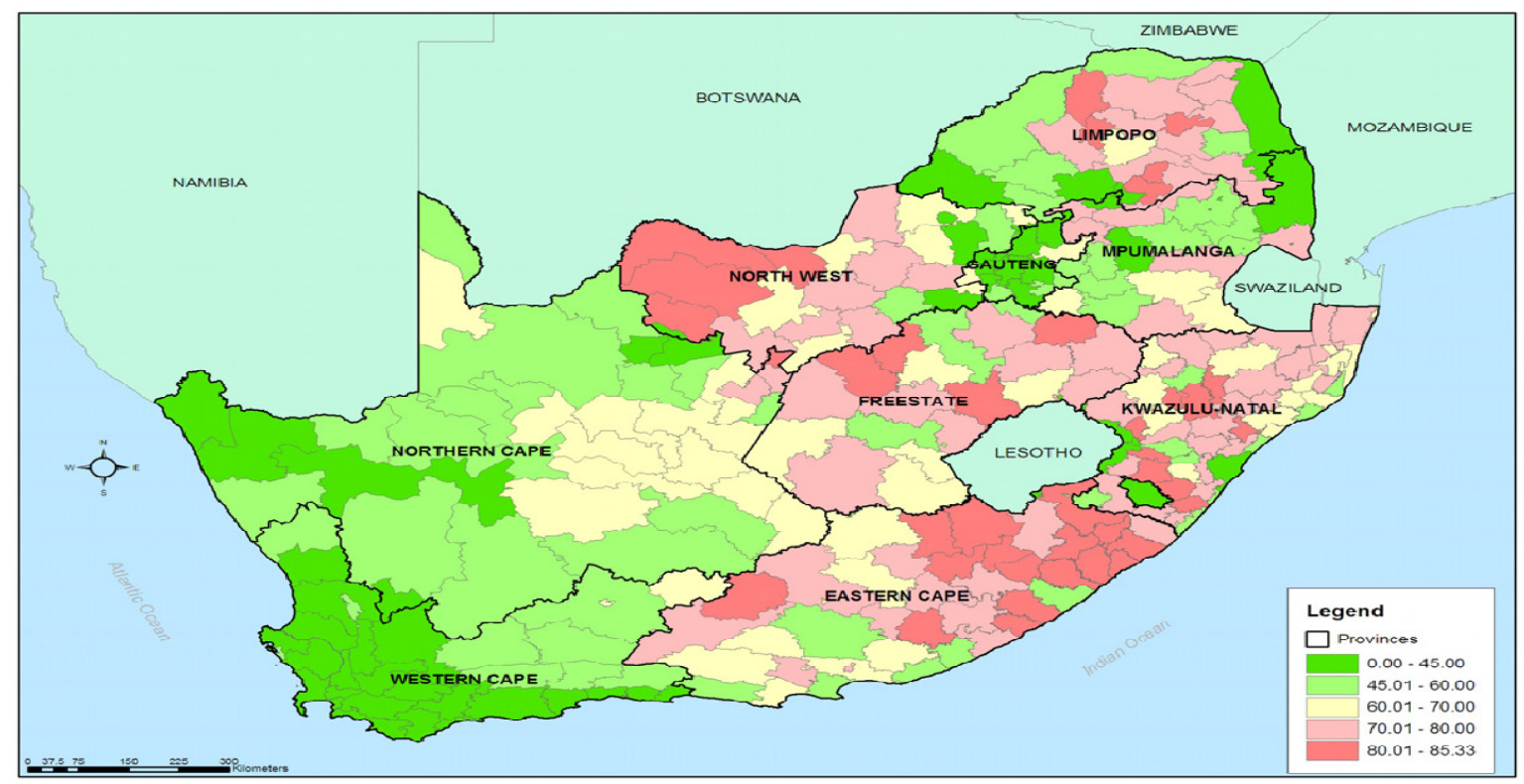

Figure 2. Vulnerability indicators map in South Africa (StatsSA, 2006)

Data was collected making use of structured interviews. The interviews were conducted on the 50 randomly selected households. Household heads were requested to answer a set of structured questions. Some households were suspicious of the consequences of answering the questions. The tendency to associate the researcher with an informer who could get one arrested for being above the law was common. For instance, some households refused to disclose ownership of televisions for personal reasons. It was also difficult for the researcher to convince some households to give their identification information, especially the age and income information as they took such information confidential. It became apparent that the respondents misunderstood the nature of the questions at first However, once the respondents understood the pure academic nature of the research, they provided the information that was needed.

The main analytical technique used was descriptive statistics. The purpose of using this analysis was to determine and compare rural household's asset portfolio status and their food access. Existing gaps were also identified to determine food access in terms of household assets. Data analysis was based on the research questions designed at the beginning of the research. Food accessibility categories and percentages were used to analyse data. Responses in the questionnaires were tabulated, coded and processed by the use of statistical Package for Social Sciences (SPSS) programme.

In order to develop household food accessibility profile categories, information on human, social, financial, natural and physical assets was analysed using criteria shown in Table 1. Households were categorised as follows:

Food insecure (FI), Vulnerable (VU), Marginally food secure (MFS) and Food secure (FS)

From the definitions and measurements of food accessibility presented in Table 1, the total of 50 households were grouped into Food insecure $\left(\mathrm{n}_{1}=30\right)$, Vulnerable $\left(\mathrm{n}_{2}=8\right)$, Marginal $\left(\mathrm{n}_{3}=7\right)$, and Food secure $\left(\mathrm{n}_{4}=5\right)$. The descriptions of variables used to describe household human assets are presented in Table 2. The variables included all human assets, namely gender (gen), employment (emp) and education (edu). 
Table 1 . Household food accessibility categories used in the study

\section{Food insecure}

Households with income and consumption below US\$1.6 1 /cap/day; showing decrease in total, food and nonfood expenditures, including households unable to further decrease their expenditure patterns and with no education. Variable used in the analysis: "No education" $(\mathrm{edu})=1 ; 0=$ otherwise

\section{Vulnerable}

Households showing both income and consumption below US\$ 2.2/cap/day except households showing no decrease in expenditure patterns (categorized as marginally secure), and living in an area with little or no sanitation. Variable used in the analysis: "No sanitation" $(\operatorname{san})=5 ; 0=$ otherwise

\section{Marginal}

Households showing either income or consumption above US\$2.2/cap/day (not both), with both income and consumption between US\$1.6 and US $\$ 12.2 / \mathrm{cap} /$ day but show no decrease in expenditure patterns, and with no access to water source. Variables used in the analysis: "No water source" $(\mathrm{h} 2 \mathrm{o})=1 ; 0=$ otherwise

\section{Food secure}

Households with income and consumption above US\$2.2/cap/day, with income or consumption between US\$1.6 and US\$2.2/cap/day but show no decrease in total food and non-food expenditure, and fully employed on the farm. Variable used in the analysis:

"Fulltime employment on farm" (act) $=2 ; 0=$ otherwise

Household food accessibility categories used in the study; Source: CFSVA, 2007; CFSVA, 2007

${ }^{1} 1 \mathrm{US} \$=\mathrm{R} 8.333$

Table 2. Variables used to describe households human assets characteristics

\begin{tabular}{|c|c|}
\hline Assets & Description \\
\hline Human Assets & \\
\hline Gender (gen) & $0=$ female $; 1=$ male \\
\hline Employment (emp) & $\begin{array}{l}1=\text { working full-time } 2=\text { working part time } ; 3=\text { casual jobs; } 4=\text { unemployed; } \\
5=\text { pre-school } 6=\text { student } ; 7=\text { pensioner } ; 8=\text { housewife }\end{array}$ \\
\hline Education (edu) & $\begin{array}{l}1=\text { no education } ; 2=\text { some primary } ; 3=\text { primary completed } \\
4=\text { some secondary } 5=\text { secondary } 6=\text { post secondary } ; 7=\text { certificates } \\
8=\text { degree } ; 10=\text { post graduate }\end{array}$ \\
\hline
\end{tabular}

Variables used to describe households human assets characteristics

\section{Results and Discussion}

The results presented in Table 3 show that 84 per cent of the total 50 households sampled were female headed and 16 per cent were male headed. Among the food insecurity group 83.3 per cent of 30 households were female headed and 16.7 per cent headed by males. In the vulnerable group 87.5 per cent of 8 households were headed by females and 12.5 per cent headed by males. In the marginal group 85.7 per cent of 7 households were headed by females and 14.7 per cent were headed by males. Again in food secure group 60 per cent of 5 households were headed by females and 40 per cent headed by males. The results indicate that female households constitute a significant number of economically active populations in Mamone village and also reflect what is expected from the literature that female headed households usually fall within the vulnerable, marginal and food insecure categories (FAO, 2006).

Table 3. Food access in terms of household gender

\begin{tabular}{lccccc}
\hline & $\begin{array}{c}\text { Food insecure } \\
\mathrm{n}_{1}=30\end{array}$ & $\begin{array}{c}\text { Vulnerable } \\
\mathrm{n}_{2}=8\end{array}$ & $\begin{array}{c}\text { Marginal } \\
\mathrm{n}_{3}=7\end{array}$ & $\begin{array}{c}\text { Food secure } \\
\mathrm{n}_{4}=5\end{array}$ & $\begin{array}{c}\text { Total } \\
\mathrm{N}=50\end{array}$ \\
\hline & $(\%)$ & $(\%)$ & $(\%)$ & $(\%)$ & $(\%)$ \\
Male & 16.7 & 12.5 & 14.3 & 40 & 16 \\
Female & 83.3 & 87.5 & 85.7 & 60 & 84 \\
Total & 100 & 100 & 100 & 100 & 100 \\
\hline
\end{tabular}

Food access in terms of household gender. 
Table 4 shows that 62 per cent of the total 50 households were pensioners and 18 per cent were housewives. Out of 50 households, 14.0 percent were unemployed, indicating that only 6 per cent of 50 households were working fulltime on the farm. In the food insecurity group 83.3 per cent of 30 households were pensioners and 6.7 per cent were housewives. Among the vulnerable group 100 per cent of 8 households were pensioners. In the marginal group 71.4 per cent of 7 households were pensioners and 14.3 per cent were housewives. Again in the food secure group 40 per cent of 5 households were pensioners, 40 per cent were housewives and only 20 per cent were working fulltime. The results suggest that government support services continue to play an important role as a source of income. It could also be noted from Table 4 that in the food secure group 40 percent of households were unemployed. Further analysis revealed that these households were actively farming and producing food for household use.

Table 4. Food access in terms of household employment

\begin{tabular}{lccccc}
\hline & $\begin{array}{c}\text { Food insecure } \\
\mathrm{n}_{1}=30\end{array}$ & $\begin{array}{c}\text { Vulnerable } \\
\mathrm{n}_{2}=8\end{array}$ & $\begin{array}{c}\text { Marginal } \\
\mathrm{n}_{3}=7\end{array}$ & $\begin{array}{c}\text { Food secure } \\
\mathrm{n}_{4}=5\end{array}$ & $\begin{array}{c}\text { Total } \\
\mathrm{N}=50\end{array}$ \\
\hline \multirow{3}{*}{ Unemployment } & $(\%)$ & $(\%)$ & $(\%)$ & $(\%)$ & $(\%)$ \\
Pensioner & 10 & 0 & 14.3 & 40 & 14 \\
Housewife & 83.3 & 100 & 71.4 & 0 & 62 \\
Total & 6.7 & 0 & 14.3 & 40 & 18 \\
\hline
\end{tabular}

The results presented in Table 5 shows that 60 per cent of the total 50 households had no education and 20 per cent had some primary education. Among food insecure group 100 per cent of 30 households had no education. In the vulnerable group 87.5 per cent of 8 households had no education and 12.5 per cent had some primary education. In the marginal group 100 per cent of 7 households had no education. Finally in the food secure group 40 per cent of 5 households had secondary education and 20 per cent had degree. The results indicate a serious limitation for households to access food. Lack of education has been found to correlate strongly with hunger and food insecurity (FAO, 2006).Education has been found to be a key to poverty reduction, increased education has been found to improve the livelihoods of the poor and reduce the likelihood of becoming poor (Heckman, 1999).

Table 5. Food access in terms of household education

\begin{tabular}{lccccc}
\hline & $\begin{array}{c}\text { Food insecure } \\
\mathrm{n}_{1}=30\end{array}$ & $\begin{array}{c}\text { Vulnerable } \\
\mathrm{n}_{2}=8\end{array}$ & $\begin{array}{c}\text { Marginal } \\
\mathrm{n}_{3}=7\end{array}$ & $\begin{array}{c}\text { Food secure } \\
\mathrm{n}_{4}=5\end{array}$ & $\begin{array}{c}\text { Total } \\
\mathrm{N}=50\end{array}$ \\
\hline & $(\%)$ & $(\%)$ & $(\%)$ & $(\%)$ & $(\%)$ \\
No education & 100 & 87.5 & 100 & 20 & 60 \\
Some primary & 0 & 12.5 & 0 & 20 & 20 \\
Secondary & 0 & 0 & 0 & 40 & 18 \\
Degree & 0 & 0 & 0 & 20 & 2 \\
Total & 100 & 100 & 100 & 100 & 100 \\
\hline
\end{tabular}

Food access in terms of household education.

The descriptions of variables used to explain natural and social assets employed are presented in Table 6 . The variables included all natural and social assets, namely water source (h2o), water cleanness (cle) and membership to a local social organisation or society (org). The results in Table 7 shows that 90 per cent of the total 50 households used a spring/well as a water source and 10 per cent had a tap with piped water inside the houses. In the food insecure group 86.5 per cent of 30 households used a spring/well and 13.3 per cent had a tap with piped water in the houses. Among the vulnerable group 87.5 per cent of 8 households used a spring/well and 12.5 per cent had a tap with piped water in the houses. In the marginal group 100 per cent of 7 households used a spring/well while in the food secure group 80 per cent of the 5 households used a spring/well and 20 per cent had a tap with piped water in the house. 
From Table 7 there appears to be no significant pattern in terms of having access to food and a tap with piped water in the house. However, due the small sub-sample sizes it is possible that a significant pattern does not show. It could be beneficial to repeat this study on a larger scale to determine if having piped water inside the house plays a significant role in having access to food in Mamone village.

Table 6. Variables used to describe households natural and social assets characteristics

\begin{tabular}{ll}
\hline Assets & Description \\
\hline Natural Assets & \\
Water source (h2o) & $1=$ tap in house; $2=$ tap in yard; $3=$ communal tap; $4=$ spring/well; $5=$ river; \\
& $6=$ truck; $7=$ handcart/ hawker; $8=$ borehole; $9=$ other; $10=$ no regular source \\
Water cleanness (cle) & $1=$ always; $2=$ most of the time; $3=$ some of the time; $4=$ never \\
Social Assets & $1=$ burial society; $2=$ agricultural associations; $3=$ local stockvels; $4=$ football \\
Local & Association \\
membership(org) &
\end{tabular}

Variables used to describe households natural and social assets characteristics

Table 7. Food access in terms of household natural and social assets

\begin{tabular}{llllll}
\hline & $\begin{array}{l}\text { Food insecure } \\
\mathrm{n}_{1}=30\end{array}$ & $\begin{array}{l}\text { Vulnerable } \\
\mathrm{n}_{2}=8\end{array}$ & $\begin{array}{l}\text { Marginal } \\
\mathrm{n}_{3}=7\end{array}$ & $\begin{array}{l}\text { Food secure } \\
\mathrm{n}_{4}=5\end{array}$ & $\begin{array}{l}\text { Total } \\
\mathrm{N}=50\end{array}$ \\
\hline Water source: & $(\%)$ & $(\%)$ & $(\%)$ & $(\%)$ & $(\%)$ \\
Tap in house & 13.3 & 12.5 & 100 & 20 & 10 \\
Spring / well & 86.7 & 87.5 & 0 & 80 & 90 \\
Total & 100 & 100 & 100 & 100 & 100 \\
Water cleanness: & & & & & \\
Always & 3.3 & 0 & 14.3 & 40 & 4 \\
Never & 96.7 & 100 & 85.7 & 60 & 96 \\
Total & 100 & 100 & 100 & 100 & 100 \\
Local membership: & & & & & 96 \\
Burial society & 100 & 100 & 100 & 80 & 4 \\
Agric association & 0 & 0 & 0 & 20 & 100 \\
Total & 100 & 100 & 100 & 100 & \\
\hline
\end{tabular}

Food access in terms of household natural and social assets.

It was not surprising that most households had no access to clean water. This was because of the water source they used. Table 7 shows that 96 per cent of 50 households had no access to clean water as compared to 4 per cent of households who had access to clean water. The same trend is shown in the categories, whereby in food insecurity group 96.7 per cent of 30 households had no access to clean water and 3.3 per cent had access to clean water. In the vulnerable group 100 per cent of 8 households had no access to clean water. In the marginal group 85.7 per cent of 7 households had no access to clean water and 14.3 per cent had access to clean water. In all per cent of 5 households in the food secure group had no access to clean water and 40 per cent had access to clean water.

This has a very serious implication for food accessibility, because without clean and hygienic water households will experience problems in accessing and cooking healthy food. Questionable cleanliness of water is also connected with diseases and unhealthy human and physical conditions as a means of determining the extent of supportive social asset, respondents were asked on whom their household's relied in difficult times. The results indicate that 96 per cent of the total 50 households were relying on burial societies and 4 per cent relied on agricultural association as shown in Table 7 . The results in different food accessibility categories also show that burial societies were popular among households, with 100 per cent of 30 households in food insecure group relying 
on burial societies. In the vulnerable group 100 per cent of 8 households were relying on burial societies. Again in the marginal group 100 per cent of 7 households were relying on burial societies. Finally in the food secure group 80 per cent of 5 households were relying on burial societies and 20 per cent were relying on agricultural association. The implication is to encourage households to be involved in other local organisation, where they buy groceries and share among themselves. This could enable them to become more food secure in future as is revealed by Putnam (1993) in this regard. The descriptions of variables employed in the description of financial assets are presented in Table 8. The variables include all financial assets, namely income source (act), and expenditure (ren). Table 9 shows that pensions are the main source of income for households. In all 52 per cent of the total 50 households surveyed received income from pensions and 16 per cent from government grants. In the different food accessibility categories, pensions still served as a main source of income, 70 per cent of 30 households in the food insecure group received income from pensions. In the vulnerable group 75 per cent of 8 households received income from pensions and about 42.9 per cent of 7 households in the marginal group received income from pensions.

Table 8. Variables used to describe households financial assets characteristics

\begin{tabular}{|c|c|}
\hline Assets & Description \\
\hline \multicolumn{2}{|l|}{ Financial Assets } \\
\hline Income source (act) & $\begin{array}{c}1=\text { informal employment; } 2=\text { fulltime employment; } 3=\text { seasonal employment; } 4 \\
=\text { grants; } 5=\text { remittances; } 6=\text { pensions; } 7=\text { selling snacks }\end{array}$ \\
\hline Expenditure (ren) & $\begin{array}{c}1=\text { none } ; 2=\mathrm{R} 1-\mathrm{R} 1993=\mathrm{R} 200-\mathrm{R} 399 ; 4=\mathrm{R} 400-\mathrm{R} 599 ; 5=\mathrm{R} 600-\mathrm{R} 799 ; 6=\mathrm{R} 800 \\
\text {-R999; } 7=\mathrm{R} 1000-\mathrm{R} 1499 ; 8=\mathrm{R} 1500-\mathrm{R} 2999=\mathrm{R} 3000-\mathrm{R} 6999 ; 10=\mathrm{R} 7000-\mathrm{R} 899911 \\
=\mathrm{R} 9000-\mathrm{R} 13999 ; 12=+\mathrm{R} 14000\end{array}$ \\
\hline
\end{tabular}

Variables used to describe households financial assets characteristics.

Table 9. Food access in terms of household income sources

\begin{tabular}{llllll}
\hline & $\begin{array}{c}\text { Food insecure } \\
\mathrm{n}_{1}=30\end{array}$ & $\begin{array}{l}\text { Vulnerable } \\
\mathrm{n}_{2}=8\end{array}$ & $\begin{array}{l}\text { Marginal } \\
\mathrm{n}_{3}=7\end{array}$ & $\begin{array}{l}\text { Food secure } \\
\mathrm{n}_{4}=5\end{array}$ & $\begin{array}{l}\text { Total } \\
\mathrm{N}=50\end{array}$ \\
\hline $\begin{array}{l}(\%) \\
\text { Informal }\end{array}$ & 3.3 & $(\%)$ & $(\%)$ & $(\%)$ & $(\%)$ \\
Employment & 3.3 & 0 & 0 & 0 & 4 \\
Full time & & 0 & 4.3 & 100 & 10 \\
$\begin{array}{l}\text { Employment on the farm } \\
\text { Government }\end{array}$ & 10 & 12.5 & 14.3 & 0 & 16 \\
$\begin{array}{l}\text { Grants } \\
\text { Remittances }\end{array}$ & 10 & 12.5 & 14.3 & 0 & \\
Pensions & 70 & 75 & 42.9 & 0 & 52 \\
Selling snacks & 3.3 & 0 & 14.3 & 0 & 4 \\
Total & 100 & 100 & 100 & 100 & 100 \\
\hline
\end{tabular}

Food access in terms of household income sources.

In the food secure group 100 per cent of 5 households received income from full time employment. This result indicates the role of government support services does assist in having limited access to food but the important role that job creation could play in ensuring access to food should be recognised as a primary influencing factor to having food access, bearing in mind that the category of food secure rests on having full-time employment. Table 10 shows monthly expenditure of households. The results show that 40 per cent of the total 50 households spend R600-R 799 monthly. Thirty percent of total 50 households spend R 800-R 999 monthly. In the food insecure group 40 per cent of 30 households spend R800-R999 monthly and 36.7 per cent spend R600-R799 monthly. 
Again in the vulnerable group 75 per cent of 8 households spend R600-R799 monthly and 12.5 per cent spend R400-R599 and R200-R399 respectively in a month.

Table 10. Food access in terms of household expenditure

\begin{tabular}{llllll}
\hline & Food insecure & Vulnerable & Marginal & Food secure & Total \\
& $\mathrm{n}_{1}=30$ & $\mathrm{n}_{2}=8$ & $\mathrm{n}_{3}=7$ & $\mathrm{n}_{4}=5$ & $\mathrm{~N}=50$ \\
\hline R1-R199 & $(\%)$ & $(\%)$ & $(\%)$ & $(\%)$ & $(\%)$ \\
R200 -R 399 & 6 & 0 & 0 & 0 & 0 \\
R400-R599 & 10 & 12.5 & 14.3 & 0 & 8 \\
R600 -R 799 & 36.7 & 12.5 & 28.6 & 0 & 6 \\
R800 -R 999 & 40 & 75 & 0 & 20 & 40 \\
R1000 -R 1499 & 3.3 & 0 & 42.9 & 0 & 30 \\
R1500 -R 2999 & 3.3 & 0 & 0 & 20 & 6 \\
R3000-R6999 & 0 & 0 & 14.3 & 40 & 8 \\
+R14000 & 0 & 0 & 0 & 0 & 0 \\
Total & 100 & 0 & 0 & 20 & 2 \\
\hline
\end{tabular}

Food access in terms of household expenditure.

In the marginal group 42.9 per cent of 7 households spend R800-R999 monthly and 28.6 per cent used R400-R599 monthly. In the food secure group 40 per cent of 5 households spend R1500-R2999 monthly. These results are not surprising as 52 per cent of households shown in Table 9 rely on pensions as their income source. This will have a very serious impact on how households pay for food and other necessities. The descriptions of variables used to explain physical assets employed are presented in Table 11. The variables included type of dwelling (dwe). According to Makhura (2004) the characteristics of the dwellings in which household's live provide an important indication of the well-being of household's members. About 62 per cent of 50 households do not satisfy the characteristics of a good dwelling. Only 10 per cent of 50 households have their dwellings build with bricks under tiles.

Table 11. Variables used to describe household's physical assets characteristics

\begin{tabular}{ll}
\hline Assets & Description \\
\hline Physical Assets & \\
Type of dwelling (dwe) & $\begin{array}{l}1=\text { brick under asbestos; } 2=\text { brick under tiles; } 3=\text { bricks under corrugated sheets; } \\
4=\text { bricks under thatched roof; } 5=\text { pole and mud under thatch; } 6=\text { pole and mud } \\
\end{array}$ \\
& under asbestos
\end{tabular}

Variables used to describe household's physical assets characteristics.

Table 12 further shows that in food insecurity group 70 per cent of 30 households used brick under corrugated iron and 20 per cent used pole and mud under thatch. In the vulnerable group 62.5 per cent of 8 households used pole and mud under thatch and 25 per cent used brick under corrugated iron. In the marginal group 42.9 per cent of 7 households used brick under corrugated and 28.6 per cent used bricks under tiles. Again in the food secure group 40 per cent of 5 households used bricks under corrugated iron and 40 per cent used bricks under tiles. Although this indicates a limited socio-economic development in the village there is potential to practice rainwater harvesting from dwellings that make use of corrugated iron or tiles. 
Table 12. Food access in terms of household dwelling

\begin{tabular}{lccccc}
\hline & Food insecure & Vulnerable & Marginal & Food secure & Total \\
& $\mathrm{n}_{1}=30$ & $\mathrm{n}_{2}=8$ & $\mathrm{n}_{3}=7$ & $\mathrm{n}_{4}=5$ & $\mathrm{~N}=50$ \\
\hline & $(\%)$ & $(\%)$ & $(\%)$ & $(\%)$ & $(\%)$ \\
Bricks under Tiles & 6.7 & 0 & 28.6 & 40 & 10 \\
Brick under Asbestos & 0 & 0 & 0 & 20 & 2 \\
Brick under Corrugated & 70 & 25 & 42.9 & 40 & 62 \\
Pole and mud under thatch & 20 & 62.5 & 14.3 & 0 & 24 \\
Pole and mud under asbestos & 0 & 0 & 20 & 0 & 2 \\
Total & 100 & 100 & 100 & 100 & 100 \\
\hline
\end{tabular}

Food access in terms of household dwelling.

\section{Conclusions}

This study was based on assets portfolios and food accessibility in a village in Limpopo province. Two analytical tools were used to accomplish this, including descriptive analysis and comprehensive food security and vulnerability analysis. By using these types of analysis, the aim was to achieve the three objectives of the study, namely: Differentiate categories for household's food access in terms of household assets: This was achieved through the use of comprehensive food security and vulnerability analysis. Different categories were identified namely; food insecure, vulnerable, marginal and food secure categories.

It was well established that lack of food accessibility was largely driven by poor household's lack of productive assets essential for food production, the meagre contribution of subsistence agriculture to households food needs, a relatively high dependence on government support services and limited access to good water sources. The study indicates that households in Mamone village generally have a small economic base meaning few people are involved in providing services and products to their local economy, implying that a large proportion of the population reside in areas with few employment opportunities and therefore creating high unemployment rate as discussed in the results. This implies that households would look towards other source of income such as remittances, government grants and pensions in order to secure food accessibility in an environment where food production is minimal.

\section{Recommendations}

It is very clear from the results that a wide range of interventions is required-ranging from emergency food relief and other forms of social protection, to measures aimed at ensuring more effective participation of people in the formal and informal economies. Policy focus on improving water, sanitation, inadequate health services and improving access to nutritious foods through agricultural interventions would help to address these problems. The national and provincial Departments of Health, social development and Agriculture need to proactively address these issues.

\section{References}

FAO. (2006). The state of food insecurity in the world: eradicating world hunger-taking stock ten years after world food summit, Rome: FAO.

Financial scope. (2005). Household financial survey, Retrived June 10, 2008 from http: // www.finscope.co.za (Accessed 10 June 2008).

Gass, T., \& Heierli. (2001). Enhancing employment and income generation in rural areas, Rural poverty report, IFAD.

Heckman, J. L. (1999). Casual parameters and policy analysis in economics: a twentieth century retrospective. NBER working paper 7333. National bureau of economic research, Inc.

Makhura, M. N. (2004). Facing rural poverty. South African rural development quarterly, 2(Q3), 21.

Mbeki, T. (2005). Address at the national council of provinces in Limpopo, Available from: http://www.dfa.gov.za Accessed 04 November 2007.

Putnam, R. D. (1993). The prosperous community: social capital and public life. American prospect, 4, 13. 
StatsSA (Statistics South Africa). (2003). Household survey, Retrived September 2, 2007 from http:// www.statssa.gove.za

StatsSA (Statistics South Africa). (2006). Limpopo province profile, Report-00-91-09, Pretoria.

Vogel, C., \& Smith, J. (2002). The politics of scarcity: Conceptualizing the current food security crisis in Southern Africa. South African journal of science, 98. 